\title{
HIDUP SEHAT BERSAMA YOGA
}

Oleh:

\author{
I Made Dwitayasa \\ Dosen Fakultas Brahma Widya IHDN Denpasar
}

\begin{abstract}
:
Yoga is an archaeological discovery at the time of culture in the city of Harappa and Mahenjadaro, which is embodied in a statue of Lord Shiva and Goddess Parvati who was doing a variety of different asanas, where there is a belief that Lord Shiva is a yoga teacher while Goddess Parvati is a student. Maharsi Patanjali in the Yoga known as Raja Yoga or yoga Astangga with eight members, namely Yama, Nyama, Asana, Pranayama, Pratyahara, Dharana, and Samadhi Dhyna. Of the eight sections in the first five sections form the outer member (Bahir-yoga) of yoga or make your body fresh and healthy, because it contains about body movements contained in the teachings of yoga, while this part of the last three limbs form in the so-called intertine.
\end{abstract}

Keywords: yoga; healthy

Abstrak:

Yoga ditemukan sebagai sebuah penemuan arkeologis pada jaman kebudayaan kota Mahenjodaro dan Harappa, dengan ditemukannya patung Dewa Siwa dan dewi Parwati yang sedang berada pada berbagai jenis asana yang berbeda-beda. Diyakini bahwa Siwa adalah guru sementara Parwati adalah seorang murid. Maharsi Patanjali dalam Yoga diketahui sebagai Raja Yoga atau Astangga Yoga dengan delapan bagiannya, yakni Yama, Nyama, Asana, Pranayama, Pratyahara, Dharana, Dhyana dan Samadhi. Lima bagian awal dari kedelapan bagian tersebut adalah bersifat luaran atau Bahir Yoga yang menjadikan badan sehat dan segar karena terdiri dari gerakan-gerakan seluruh bagian badan. Sementara ketiga bagian berikutnya adalah bagian dalam atau antarangga, karena bekerjanya di wilayah pikiran.

Kata Kunci yoga, sehat, astangga,

\section{Pendahuluan}

Setiap manusia menginginkan kesehatan, karena kesehatan adalah sesuatu yang sangat berharga dan sangat penting di dalam menjalani sebuah kehidupan. Semua orang selalu menginginkan hidup sehat, bahagia dan sejahtera, namun bagaimana cara hidup sehat, dan bagaimana cara menjadikan diri yang sehat masih belum banyak yang mengetahuinya. Hidup yang sehat adalah terjadinya keseimbangan antara tubuh dan pikiran, sehingga mendapatkan suatu ketenangan dan kedamaian.

Yoga merupakan salah satu sarana untuk mencapai kesehatan baik jasmani maupun rohani. Penemuan yoga merupakan penemuan kepurbakalaan pada jaman kebudayaan di kota Harappa dan Mahenjadaro, yang diwujudkan dalam sebuah patung Dewa Siwa dan Dewi Parwati yang sedang melakukan berbagai asanas yang berbeda, di mana ada sebuah keyakinan bahwa Dewa Siwa adalah sebagai guru yoga sedangkan Dewi Parwati adalah sebagai muridnya (Yudhiantara dalam Dwitayasa, 2013:80).

Kata yoga berasal dari kata "yuj" yang artinya menghubungkan, sedangkan yoga mengandung arti pengendalian aktivitas pikiran dan merupakan roh pribadi dengan roh tertinggi. Yoga didirikan oleh Maharsi Patanjali yang merupakan tambahan dari filsafat Samkhya di mana yoga secara langsung mengakui sebagai asal mula alam semesta beserta isinya menurut Maharsi Patanjali di dalam Raja Yoga dikenal dengan nama Astangga Yoga atau yoga dengan delapan anggota yaitu Yama, Nyama, Asana, Pranayama, Pratyahara, Dharana, Dhyna 
dan Samadhi. Dari delapan bagian tersebut di atas lima bagian yang pertama membentuk anggota luar (bahir-yoga) dari yoga atau membuat tubuh menjadi segar dan sehat, karena memuat tentang gerakan-gerakan tubuh yang tertuang dalam ajaran yoga, sedangkan tiga bagaian yang terakhir membentuk anggota tubuh bagian dalam yang disebut dengan antar-angga (Maswinara, 2006: 165).

Kelima gerakan yang tersebut di atas dilakukan dengan menggerakan organ tubuh terutama di dalam bagian asanas. Asanas atau yogasana merupakan pondasi untuk membangun jalan spiritual, bukan sekedar menggerakan atau olah tubuh belaka. Selain itu dewasa ini yoga memberikan kontribusi penting di dalan kehidupan manusia terutama di dalam dunia pengobatan modern. Ketika setiap manfaat gerakan yoga terutama asanas dieksplorasi melalui risert kesehatan dengan hasil yang sangat efektif sebagai upaya pencegahan dan pengobatan berbagai macam penyakit sehingga para pakar kesehatan dalam dekade terakhir ini banyak menulis tentang Yoga Healing yang refrensinya berasal dari Hata Yoga.

Yoga Asanas dari Hata Yoga dilakukan secara perlahan dengan perpaduan rileksasi dan konsentrasi, sehingga dengan cara ini susunan saraf, kelenjar endoktrin serta organ tubuh bagian dalam dan juga otot-otot distimulir untuk berfungsi sebagaimana mestinya. Belakangan ini yoga sangat banyak diminati oleh club-club aerobik, senam kebugaran dengan tujuan untuk kesehatan serta memberikan efek positif bagi vitalitas fisikal dan kejiwaan serta dapat menyembuhkan berbagai penyakit (Yudhiantara dalam Dwitayasa, 2013: 81).

Menurut Vimla Lalvani (2002) dalam bukunya yang berjudul Dasar-dasar Yoga mengemukakan bahwa yoga sangat populer serta cakupan diminati oleh sebagian orang karena memiliki efek terapi bagi pikiran dan tubuh, dan jika yoga dapat dikuasai dengan baik maka akan dapat menenangkan pikiran yang terlalu letih, sehingga dapat mengalirkan energi fisik dan mental ke arah yang lebih baik. Yoga juga adalah ilmu yang memiliki latar belakang ilmiah serta dikenal secara universal tanpa batasan waktu dan tetap relevan hingga kini sejak dikembangkan 2000 tahun yang lalu.

Yoga di dalam pandangan masyarakat dewasa ini masih belum populer dan bahkan masyarakat menganggap yoga adalah sesuatu yang identik dengan mistik dan berbagai sebuatan lainnya. Masyarakat juga beranggapan bahwa yoga adalah milik orang-orang tertentu saja seperti Pendeta, Sampradaya, sehingga minat masyarakat untuk mempelajari yoga sangatlah kecil, dan ditambah lagi dengan berbagai isu bahwa dengan mempelajari yoga seseorang dikatakan mempelajari hal-hal yang aneh, mistik dan sebagainya. Namun bagi masyarakat yang telah memiliki pengetahuan yang tinggi berpandangan lain yaitu dengan mempelajari yoga dapat menyehatkan tubuh, sekaligus menenangkan pikiran, serta banyak manfaat lainnya yang dapat diperoleh melalui gerakan-gerakan yoga.

Manfaat yoga adalah selain dapat membuat tubuh menjadi sehat juga dapat membentuk tubuh lebih baik, meningkatkan kelenturan, stamina, dan mengencangkan otot. Selain itu peregangan juga dapat melepaskan ketegangan dalam kelompok otot yang berbeda jika dikombinasikan dengan teknik bernafas yang benar peregangan dapat mengurangi strees pada sistem saraf dan dapat meningkatkan energi, memperkuat tubuh serta dapat meningkatkan kesehatan.

Dari pemaparan di atas dapat ditarik sebuah benang merah bahwa yoga merupakan salah satu cara untuk meningkatkan kesehatan tubuh, yaitu melalui gerakan-gerakannya terutama pada asanas yang dikombinasikan dengan pranayama akan dapat menimbulkan energi yang disalurkan ke seluruh tubuh dengan tujuan akhirnya adalah untuk mendapatkan kesehatan baik lahir maupun bhatin.

Yoga Sutra yang disusun oleh Maharsi Patanjali ini adalah teks kiasik terbesar dan terutama dalam aliran filsafat Yoga India. Ditulis 2.500 tahun yang lalu; jadi kurang lebih sezaman dengan Buddha Gotama. Bahkan ada yang berpendapat bahwa teks ini telah disusun tak kurang dan abad ke-2 SM. Di dalamnya, sutra- 
sutra tentang Yoga atau penyatuan universalnya pendek dan akurat menegaskan bagian-bagian esensial secara lengkap dan rinci. Mengingat kepadatan dan kepekatan kandungan makna filosofis spiritualnya, Yoga Sutra dianjurkan agar dijelaskan dan diterjemahkan oleh seorang guru Yoga melalui komentar-komentar. Praktik Yoga dipandang sebagai pelengkap dan dalam satu kesatuan pandang dengan filsafat Sankhya. Tujuan pokoknya adalah merealisasikan kebebasan jiwa dari kungkungan maya.

Kurangnya informasi tentang Yoga telah mengundang persepsi keliru yang tak sedikit di kalangan awam. Yoga sering dikacaukan dengan Tapa, bahkan dengan sesuatu yang berbau takhayul. Atau memandangnya dari sudut pandang kegaiban dan kanuragan saja. Itu jugalah alasan yang menggugah saya untuk menulis buku ini.

Berikut ini adalah paparan Sri Swami Sivananda-pendiri The Divine Life Societytentang Yoga:

"Yoga bukanlah mengurung diri di dalam gua-gua, bukan pula berkelana di hutan-hutan lebat sekitar Pegunungan Himalaya. Ia juga bukan hanya memakan jenis makanan yang berupa sayur-mayur dari pegunungan. Brahman bukanlah pengecut yang lari dari hiruk-pikuknya komunitas dan pemukiman manusia. Praktikkan sajalah Yoga di rumah Anda sendiri. Manakala hasrat untuk mempraktikkannya muncul, ini berarti bahwa kebebasan telah berada dalam jangkauan Anda, oleh karenanya manfaatkan peluang ini sebaikbaiknya. Menjalani kehidupan sebagai seorang yogi, tidaklah mesti menelantarkan siapa pun juga atau mengabaikan kewajiban-kewajiban melekat Anda. Ia bermakna mengubah sikap hidup dan kebiasaan mengerja kan sesuatu yang sia-sia, menuju jalur yang secara pasti mengantarkan langsung kepada Tuhan. Ia dibarengi dengan perubahan perilaku dalam menjalani kehidupan serta metode-metodenya guna membebaskan diri Anda dan berbagai belenggu dan kemelekatan. Kebenaran dan pengabaian keakuan, sebenarnya merupakan masalah sikap batin."Sesuai sistematika dan teks aslinya, Kidung Kelepasan Patanjali ini pun disajikan dalam empat bagian (pada), masing-masing: SamãdhiPãda, Sãdhana Pãda, Vibhuti Pãda, Kaivalya Pãda

\section{Pembahasan}

\section{Samãdhi Pãda Hakikat Penyatuan Agung}

Pada yang tersusun dalam 51 suara ini memaparkan tentang landasan filosofis spiritual Yoga, hakikat dari penyatuan dan hakikat ketuhanan dalam Yoga. Kita juga akan menemukan paparan yang menyangkut intisari keimanan Hindu, yang juga berhampiran dengan Buddha, serta penerangan yang amat bersesuaian dengan upanishad-upanishad dan Veda Sruti. Dari bagian ini pula, bila kita cermati, kesinambungan antara Sankhya Darsana dan Vedanta terjembatani dengan shastragama-shastragama lain. Pada ini merupakan pembuka yang berisi pembekalan pada tahp persiapan, sebagai landasan, dan kerangka dasar seorang sadhaka, seorang penekundijalanspiritual.

Samadhi Pada terutama menjelaskan beberapa jenis Samadhi sesuai dengan tersisa atau tidaknya objek di dalam Samadhi, yang dicapai bersama dengan terhentinya pusaranpusaran pikiran. Kaivalya, yang merupakan isu sentral dari Yoga Sutra ini, hanya dicapai melalui Nirvikalpa atau Nirbija Samadhi. Walaupun demikian, jenis pencapaian lain tetap merupakan pencapaian tinggi yang merupakan penghampiran pra yang tertinggi. Pembekalan mendasar, seperti ketidak-melekatan (Vairagya) dan pembiasaan laku-spiritual (Abhyasa) juga diberikan, sebelum seorang sadhaka terjun dalam praktik kehidupan spiritual secara intens.

\section{Sadhana Pada Paparan Praktis Praktek Spiritual}

Sutra ini tersusun 55 Sutra memberikan paparan praktis bagi seorang sadhaka. Di sini akan diperkenalkan Yama, Niyama, Pranayama, dan Pratyahara, serta persiapan untuk memasuki tiga serangkai - Samyama-Dharana-DhyanaSamadhi. Metode pembebasan psikologis dan spiritual yang terdiri dari delapan tahapan ini, juga dikenal dengan Ashtanga Yoga. Di sini juga diingatkan akan bahaya dari siddhi bagi seorang 
sadhaka sejati. Secara keseluruhan prinsip-prinsip praktis dari Yoga akan dipaparkan secara lugas. Ketika mengikuti Sadhana Pada ini, kita seakanakan sedikit "dipaksa" untuk memahami sistem Yoga praktis tertentu, terutama Hatha Yoga dan Laya Yoga atau Kundalini Yoga.

\section{Vibhuti Pada-Paparan tentang Kekuatan dan Kesempurnaan}

Di sini dipaparkan tuntunan praktis yang lebih tinggi, terutama mengenai tiga serangkai Sam yama, melalui kekuatan spiritual, kegaiban, hingga kesempurnaan Yoga bisa dicapai. Bagi mereka yang memiliki naluri mistis yang kuat, bagian yang tersusun dan 56 sutra ini akan menjadi bagian yang paling menarik. Di sini juga disampaikan petingatan-peringatan untuk tidak melaksanakan Yoga hanya demi perolehan kekuatan dan kegaiban itu, apalagi terikat padanya. Karena dapat dengan mudah menjatuhkan sang penekun.

\section{Kaivalya Pada - Menggapai Kebebasan Sejati}

Di antara keempat pada, Kaivalya Pada inilah yang tersingkat. Paparannya padat, berfokus pada pencapaian Kaivalya dan tentang bagaimana seorang yogi yang telah mencapai status itu. Di sini Patanjali tak lupa menyelipkan tatanan etikamoral luhur dari seorang yogi sempurna - yang dalam ajaran Vedanta dikenal sebagai Jivanmukti, ia yang telah terbebaskan dari siklus Samsara dan tak terlahirkan kembali di alam mana pun - di antara 34 suara pembentuknya.

Jadi, secara keseluruhan, keempat pada benar-benar membentuk satu kesatuan integral, yang kait-mengkait satu sama lain, mengalir dan berlanjut, saling memperjelas dan mempertegas. Yang juga meminta praktisi mempelajari Yoga Sutra guna memperoleh pemahaman yang lebih baik tentang praktik Yoga itu sendiri - secara berulang-ulang. Pada ini merupakan manualpraktis yang tersaji dalam satu kesatuan bahasan komprehensif, menyeluruh, dan terpadu. Guna menunjang bahasan-bahasan, dengan segala kerendahan hati, di akhir buku ini saya menyajikan sebuah tulisan lepas sebagai apendiks.

Pada kesempatan yang bersahaja ini kita bersyukur dan bersujud dengan penuh hormat kepada Maharsi Patanjali, atas kemurahan hati beliau tanpa pamrih telah menyusun sistematika praktis serta melahirkan satu aliran filsafat (dharsana) agung yang tiada duanya, yang dapat mengantarkan manusia menuju kebebasan sejati..

Seperti dilansir dari webmd, Senin (13/7/2009) setidaknya ada 8 manfaat yang paling banyak terasa dari yoga. Para praktisi yoga sendiri menolak jika yoga dikaitkan dengan satu agama tertentu.

\section{Sehat Bersama Yoga}

Yogi Gherada meyatakan setiap setiap orang dalam kondisi badan yang sehat, menarik nafas sebanyak 21.600 per hari. Jika pernafasan yang dilakukan oleh manusia setiap hari dikembangkan melalui latihan pranayama maka akan membuat manusia bertambah usia/umur panjang. Dalam filsafat yoga dikatakan apabila manusia tidak memahami tentang system pernafasan sebagaimana mestinya orang tidak akan bias hidup sehat. Latihan pernafasan tidak hanya penting untuk tubuh melainkan juga untuk meningkatkan ketenangan pikiran

\section{Manfaat Yoga Bagi Tubuh: \\ Fleksibilitas}

Ketika beberapa orang berpikir tentang yoga, mereka membayangkan seperti fitnes, dan mereka merasa terlalu tua, dan tidak fit untuk melakukan yoga. Salah satu bagian dari yoga disebut asanas yang bekerja secara aman untuk streching otot anda. Proses ini melepaskan asam laktat yang biasanya menyebabkan kekakuan, ketegangan, sakit dan kelelahan. Selain itu, yoga juga meningkatkan berbagai gerakan di sendi dan meningkatkan lubrikasi di sendi. Stretch pada yoga tidak hanya untuk otot tapi untuk seluruh sel-sel tubuh anda. Dalam suatu studi ditemukan bahwa terdapat peningkatan fleksibilitas sebesar $35 \%$ setelah 8 bulan melakukan yoga. Keuntungan yang paling besar adalah fleksibilitas di pundak dan badan.

\section{Kekuatan}

Beberapa gaya dari yoga seperti ashtanga dan power yoga adalah yang paling kuat dibandingkan yang lain. Mempraktikkan salah satu dari gaya ini 
akan membantu meningkatkan otot Anda. Gaya yoga yang lain seperti lyengar yoga, yang hanya berfokus pada sedikit gerakan dan pengaturan posisi yang lebih tepat, bisa meningkatkan kekuatan dan daya tahan tubuh. Beberapa gaya yang lain seperti: downward dog, upward dog, dan plank, membangun kekuatan tubuh bagian atas. Hal ini menjadi penting pada usia tertentu. Gaya berdiri, khususnya jika Anda berpaku pada berapa lama Anda bernafas, dapat membangun kekuatan pada otot harmstrings, quadriceps dan abdominal. Jika dilakukan dengan benar, hampir semua gaya tersebut membangun kekuatan inti dalam otot abdominal.

\section{Postur}

Dengan peningkatan fleksibilitas dan kekuatan akan menghasilkan postur tubuh yang lebih baik. Banyaknya gaya berdiri dan duduk akan mengembangkan kekuatan inti. Manfaat lain dari yoga adalah meningkatkan kesadaran diri kita. Kesadaran tinggi ini memberikan anda peringatan jika anda bungkuk atau slumping sehingga Anda bisa langsung menyesuaikan sikap.

\section{Pernafasan}

Pernafasan juga termasuk dalam yoga yang akan meningkatkan kapasitas paru-paru kita. Hal ini bisa meningkatkan penampilan dan kinerja kita. Tetapi, tipikal dari yoga tidak difokuskan pada aerobik fitnes seperti berjalan atau bersepeda. Sebagian besar gaya yoga menekankan pada dalam dan panjangnya nafas Anda. Ini juga yang merangsang respons relaksasi yang akan berlawanan dengan peningkatan respons dari stres.

\section{Mengurangi stres dan lebih tenang}

Beberapa gaya yoga menggunakan teknik meditasi khusus untuk membuat pikiran yang sering stres menjadi lebih tenang. Gaya yoga lainnya juga tergantung pada teknik bernafas yang mendalam untuk memfokuskan pikiran, yang membuat pikiran menjadi lebih tenang. Beberapa manfaat yoga anti-stres dihubungkan dengan biochemical, misalnya terjadi penurunan catecholamines, hormon yang dihasilkan oleh kelenjar adrenalin dalam respon terhadap stres. Menurunkan tingkat hormon neurtransmitter, dopamine, norepinephrine, epinephrine dan menciptakan rasa tenang. Beberapa penelitian memfokuskan pada peningkatan hormon oxytocin yaitu hormon yang terkait dengan rasa santai dan terhubung ke orang lain, yang memungkinkan mengapa begitu banyak romance yang dimulai di studio yoga.

\section{Konsentrasi dan mood yang lebih baik}

Hampir setiap siswa yang mengikuti kelas yoga merasa lebih bahagia dan puas. Penelitian baru-baru ini mengeksplorasi efek dari yoga pada depresi, manfaat yang didapat adalah adanya peningkatan aliran oksigen ke otak. Yoga juga disarankan sebagai terapi untuk meringankan gejala obsessive dan disorder.

\section{Jantung lebih sehat}

Mungkin salah satu manfaat dari yoga yang paling dipelajari adalah efeknya pada penyakit jantung. Yoga telah lama dikenal untuk menurunkan tekanan darah dan memperlambat denyut jantung. Manfaat dari memperlambat denyut jantung sangat berarti pada orang yang hipertensi, penyakit jantung dan stroke. Yoga adalah komponen kunci untuk program penyakit jantung yang dirancang oleh Dean Ornish, MD. Ini adalah program pertama untuk penanganan penyakit jantung dengan gaya hidup melalui diet dibandingkan dengan operasi. Yoga juga telah dikaitkan dengan penurunan tingkat kolesterol dan trigliserida serta dalam peningkatan fungsi sistem kekebalan.

\section{Memberikan efek pada kondisi medis}

Yoga telah menjadi populer di dunia barat, peneliti medis juga mulai belajar manfaat terapeutik yoga, yang disebut dengan integrative yoga atau terapi IYT. Ada yang digunakan sebagai perawatan tambahan medis untuk kondisi tertentu dari depresi klinis sampai penyakit jantung. Manfaat yoga yang lain adalah untuk kondisi medis kronis, seperti menghilangkan gejala asma, back pain dan arthritis.

Beberapa studi juga menyatakan bahwa yoga memiliki dampak positif pada pembelajaran dan memori. Untuk dapat memastikan dan merasakan manfaat dari yoga tidak ada salahnya untuk anda datang ke tempat latihan yoga, dan mulailah untuk merasakan manfaatnya. 
Rsi Patanjali dididalam ajaran astangga yoga atau yoga dengan delapan anggota yang mengandung disiplin pikiran dan tenaga fisik. Hata yoga membahas tentang cara-cara mengendalikan badan dan pengaturan pernafasan yang akhirnya memuncak pada Raja-Yoga. Hata-yoga dapat dikatakan sebagai tangga untuk mencapai tahapan Raja-Yoga. Sat-Karma yaitu enam kegiatan pemurnian badan yang terdiri dari: Dhauti yaitu pembersihan perut, Basti yaitu pembersihan usus, Neti yaitu pembersihan lubang hidung, Trataka, yaitu penatapan tanpa kedip pada suatu objek

\section{Yoga Mengendalikan Pikiran}

Menurut Rsi Patanjali, di mana beliau adalah seorangpendiri Yoga yang disebut dengan Patanjali Yoga dalam bukunya yang berjudulYoga Suyra, mendifinisikan bahwa yoga adalah pengendalian pikiran. Pengendalian pikiran diperlukan mengingat pikiran sangat mempengaruhi prilaku manusia. Jika manusia memiliki pikiran yang baik maka manusia tersebut memiliki prilaku yang baik atau senaliknya, maka dari itu pikiran perlu dikendalikan guna membantu manusia dalam mencapai tujuan hidnupnya yang lebih baik. menurut Rsi Patanjali dalam Somvir (2010: 3) menyebutkan bahwa pikiran memiliki tingkatkan sebagai berikut:

1. Ksipta: pikiran tidak tenang dan tidak bisa konsentrasi pada objek apapun

2. Mudha : yaitu pikiran yang didak dapat membedakan antara hal yang baik dan hal yang buruk

3. Viksipta: yaitu pikiran hanya menerima kenahagiaan diri sendiri dan tidak mendapatkan kesedihan

4. Ekagra: saatpikiran menarik diri dari objek-objek luar dan berkonsentrasi sehingga pikiran mulai stabil dan tenang

5. Nirodha: saat pikiran sudah stabil dan tidak ragu lagi, menghentikan hal-hal yang tidak baik, yang merupakan tahap awal dalam latihan yoga

Lebih lanjut dipaparkan bahwa sesorang yang ingin berhasil dalam yoga yang paling pertama di kendalikan adalah pikiran, harus belajar melepaskan diri dari ikatan duniawi, karena semakin terikat dengan kehidupan duniawi maka manusia semakin banyak merasakan bahagia dan sedih. Namun manusia jika sudah dapat melepaskan diri dengan duniawi maka kebahagiaan sejati akan dapat tercapai.

Dengan meninggalkan dunia bukan berarti manusia harus meninggalkan keluarga, artha, masyarakat, namun bagaimana manusia dapat mengendalikan sifat-sifat duniawi sehingga pikirantidak teromabang-ambing oleh kebahagiaan dan kesedihan. Karena pada prinsipnya jika manusia bahagia ia akan menjadi senang sehingga egonya muncul, begitu pula jika manusia sedih maka akal sehatnya tidak terkontrol maka munculah hal-hal negative dari dirinya. Untuk itu manusia perlu menumbuhkan kesdaran diri dan menarik segala bentuk objek indriya ke dalam. Dalam filsafat yoga dikatakan bahwa manusia memiliki Sembilan pintu dalam tubuhnya, seperti: kedua mata, kedua telinga, kedua lubang hidung, mulut, alat reproduksi, dan anus. Kesembilan pintu tersebut tujuh buah arahnya menghadap ke atas, dan dua buah pintu arahnya menghadap ke bawah. Pada saat melakukan yoga tujuannya adalah mengarahkan kesembilan pintu tersebut untuk mengarah ke atas.

\section{Syarat-syarat penting dalam memperkatikan Yoga}

Yoga merupakan suatu usaha atau jalan untuk mendapatkan kesehatan menurut system filsafat india dan ini telah terbukti secara nyata mamfaatnya bagi kehidupan manusia. Untuk melaksanakan yoga tidaklah dapat dilakukan secara instan namun memerlukan ketekunan dan membiasakan diri secara rutin melakukan gerakangerakan yang ada di dalam konsep yoga. Menurut Kembar (2006: 2) syarat syarat melakukan praktik yoga dapat dijelaskan sebagai berikut:

1. Bangun pagi hari sekitar jam 04.30, langsung mandi dengan air dingin, sikat gigi, buang air besar. Pada waktu mandi gosok-gosoklah badan dengan tangan, dengan mandi ini tidaklah membuat sakit malahan akan tersa lebih segar, dan mulailah sembahyang dengan mempergunakan antra dan doa yoga. 
2. Pada pukul 05.00, mulalilah berlatih atau melakukan yoga, yang diawali dengan yoga asanas dan pranayama. Mulailah dengan gerakan-gerakan yang ringan seperti: Pavanamuktasanas, mandukasana, Bhujanggasana, Salabhasana, trikonasana, Matyasana dan seterusnya. Lakukan latihan sebanyak 15 macam gerakan atau lebih, tergantung waktu yang ada. Kemudian akhiri dengan Pranayama atau latihan pernafasan, dan duduk meditasi sebanyak 5 menit sambil menghitung nafas keluar-masuk kurang lebih 30 kali

3. Selesai latihan yoga, sebaiknya minum susu dengan buah-buahan, misalnya: papaya, pisang, apel, nanas, tomat dan yang lainnya, dilanjutkan dengan sarapan pagi

4. Setiap latihan jika badan merasa letih harus istirahat satu menit, dsn setelah itu baru bias dilanjutkan kembali

5. Jangan banyak bicara atau tertawa di dalam berlatih yoga

6. Lakukan ditempat terbuka atau usahakan udara bersih keluar masuk jika melakukan yoga di dalam ruangan.

7. Pelaksanaan yoga pada sore hari sebaiknya dilaksanakan jam 16.00-19.00, selagi masih ada sinar matahari

8. Lepaskan segala benda-benda yang sekiranya mengganggu dalam gerakan yoga seperti, sepatu, cincin, gelang, arliji,dan kaca mata, sehingga membuat lebih nyaman dalam melakukan gerakan.

\section{Mantra Dan Doa Yoga}

Seperti telah anda ketahui Yoga bukan hanya memelihara kesehatan badan saja, tetapi juga kesehatan batin harus pula diperhatikan. Mantra artinya Manas + Trayas yaitu 'Membersihkan Pikiran'. Saudara harus memiliki pikiran yang bersih untuk memperoleh hasil yang baik dari pelajaran Yoga ini. Atau tidak ada gunanya anda berlatih Yoga, kalau tidak mau membersihkan pikiran! Karena pikiran lebih berkuasa daripada badan. Maka Guru-Guru Yoga selalu memulai dengan pelajaran pembersih pikiran yang dinamakan Mantra dan Doa.

Adapun urutan Mantranya sebagai berikut :

1. OM KARA MANTRA

2. GAYATRI MANTRAM

3. MANTRA SIWA

4. MANTRA MAHA MRITYUN JAYA

5. MANTRA GURU

6. DHYANA

7. MANTRAM ASATOMA

KETERANGAN :

1. OM KARA MANTRAM $=\mathrm{OM}$ (IDA SANG HYANG WIDHI) $3 \mathrm{X}$

2. GAYATRI MANTRAM $=3 \mathrm{X}$ "OM, BHUR, BWAH, SWAH

TAT SAVITUR WARENYAM

BHARGO DEWASYA DIMAHI

DYOY ONA PRASCODAYAT"

3. MANTRA SIWA

"OM NAMA SIWAYA" $=3 \mathrm{X}$

4. MAHA MRITYUM JAYA MANTRA $=3 \mathrm{X}$ "OM TRAYAM BAKAM- BAKAM YAJA MAHE

SUGANDHIM- PUSTHI VARDHANAM URVAARUKA - MUKSHEEYA - MAAM RITAT"

5. MANTRAM GURU $=3 X$

"OM GURU BRAHMA GURU WISNU

GURU DEWA MAHESVARA

GURU SAK SAT PARAM BRAHMAN

TASMAE SRI GURUVE NAMAH"

6. DHYANA MANTRA

Ucapkan OM 3 X pada saat narik nafas dan mengeluarkan nafas

7. ASTOMA MANTRA \& LOKA SAMASTA $=3 \mathrm{X}$

"ASATO MAA SAD GAMAYAM

TAMASO MAA JYOTIR GAMAYAM MITYOR MAA AMRITHAM GAMAYAM" "LOKA SAMASTA SUKINO BAWANTU LOKA SAMASTA SUKINO BAWANTU 


\section{LOKA SAMASTA SUKINO BAWANTU”}

(Kembar, 2006: 5-6)

\section{Penyakit Dan Asana Penyembuhnya}

Menurut Somvir (2010: 9-11) menyebutkan bahwa berbagai macam penyakit dapat disembuhkan dengan melakukan asanas atau gerakan-gerakan yoga. Namun harus dilakukan secara rutinitas, sungguh-sungguh, serta konsentrasi. Bila diperlukan hendaknyalah harus memiliki penuntun atau seorang Guru guna setiap gerakan yang dilakukan dapat berjalan dengan sempurna.

\begin{tabular}{|c|c|c|}
\hline no & Nama Penyakit & Asana \\
\hline 1. & Asthma (asma) & $\begin{array}{l}\text { Siddhasana, sirsasana, } \\
\text { sarvangasana, } \\
\text { matsyasana, ardha } \\
\text { matsyendriasana, } \\
\text { vajrasana, } \\
\text { bhujanggasana }\end{array}$ \\
\hline 2. & Kencing Manis & $\begin{array}{l}\text { Siddhasana, sirsasana, } \\
\text { sarvangasana, } \\
\text { matsyasana, ardha } \\
\text { matsyendriasana, } \\
\text { vajrasana, } \\
\text { Halasana, cakrsana, } \\
\text { mayurasana }\end{array}$ \\
\hline 3. & $\begin{array}{l}\text { Penyakit Prostat, } \\
\text { penyakit Paru }\end{array}$ & $\begin{array}{l}\text { Siddhasana, sirsasana, } \\
\text { sarvangasana, ardha } \\
\text { matsyendriasana, } \\
\text { vajrasana, padmasana, } \\
\text { pascimottanasana }\end{array}$ \\
\hline 4. & $\begin{array}{l}\text { Telinga, mata, } \\
\text { hidung }\end{array}$ & $\begin{array}{l}\text { Siddhasana, } \\
\text { sarvangasana, } \\
\text { matsyasana, ardha } \\
\text { matsyendriasana }\end{array}$ \\
\hline 5. & $\begin{array}{l}\text { Kandungan } \\
\text { Penyakit Perut }\end{array}$ & $\begin{array}{l}\text { sarvangasana, } \\
\text { salabhasana, } \\
\text { pascimottanasana, } \\
\text { bhujanggasana }\end{array}$ \\
\hline 6. & Darah tinggi & $\begin{array}{l}\text { vajrasana, Siddhasana, } \\
\text { matsyasana, padmasana, } \\
\text { savasana }\end{array}$ \\
\hline 7. & Darah rendah & $\begin{array}{l}\text { sarvangasana, halasana } \\
\text { pascimottanasana, } \\
\text { vajrasana, Siddhasana, } \\
\text { padmasana }\end{array}$ \\
\hline
\end{tabular}

\begin{tabular}{|c|c|c|}
\hline 8. & Tenggorokan & $\begin{array}{l}\text { Matsyasana, singhasana, } \\
\text { suptavajrasana, } \\
\text { sarvangasana }\end{array}$ \\
\hline 9. & Sakit kepala & $\begin{array}{l}\text { Pascnaimottanasana, } \\
\text { halasana, sarvangasana, } \\
\text { savasana }\end{array}$ \\
\hline 10. & Hernia & $\begin{array}{l}\text { Matsyasana, } \\
\text { sarvangasana, } \\
\text { suptavajrasana }\end{array}$ \\
\hline 11. & Jantung & $\begin{array}{l}\text { Savasana, baddha } \\
\text { padmasana, singhasana }\end{array}$ \\
\hline 12. & Susah tidur & $\begin{array}{l}\text { Sarvangasana, savasana, } \\
\text { suryanamaskar }\end{array}$ \\
\hline 13. & Haid & $\begin{array}{l}\text { Dhanurasana, } \\
\text { matsyasana, } \\
\text { suptavajrasana, } \\
\text { pascimottanasana }\end{array}$ \\
\hline 14. & $\begin{array}{l}\text { Batuk kronis, } \\
\text { bonkhitis }\end{array}$ & Matsyasana, salabhasana \\
\hline 15. & Pencernaan & $\begin{array}{l}\text { Sarvangasana, vajrasana, } \\
\text { pascimottanasana, } \\
\text { baddha padmasana }\end{array}$ \\
\hline 16. & Paru-paru, ginjal & $\begin{array}{l}\text { Sarvangasana, halasana, } \\
\text { mayurasana, baddha } \\
\text { padmasana }\end{array}$ \\
\hline 17. & Sembelit & $\begin{array}{l}\text { Halasana, mayurasana, } \\
\text { dhanurasana, } \\
\text { matsyasana, } \\
\text { padahastasana }\end{array}$ \\
\hline 18. & Kaki, tangan & $\begin{array}{l}\text { Garudasana, } \\
\text { trikonasana, utkatasana }\end{array}$ \\
\hline 19. & Diare, sakit perut & $\begin{array}{l}\text { Bahhdapadmasana, ku- } \\
\text { kutasana }\end{array}$ \\
\hline 20. & Kusta & $\begin{array}{l}\text { Sirsasana, padmasana, } \\
\text { siddhasana, singhasana, } \\
\text { gomukhasana, } \\
\text { vakrasana, vrsikasana }\end{array}$ \\
\hline 21. & Kegemukan & $\begin{array}{l}\text { Mandukasana, } \\
\text { pascimottanasana, } \\
\text { mayurasana, } \\
\text { suptavajrasana, } \\
\text { dhanurasana, ardha } \\
\text { matsyendriyasana } \\
\end{array}$ \\
\hline 22. & Terlalu banyak tidur & $\begin{array}{l}\text { Lolasana, kukutasana, } \\
\text { bakasana, uttita ekapada- } \\
\text { sirasana }\end{array}$ \\
\hline 23. & Ginjal & $\begin{array}{l}\text { Lolasana, halasana, } \\
\text { badhapadmasana, } \\
\text { padmasana, } \\
\text { suryanamaskar }\end{array}$ \\
\hline
\end{tabular}




\begin{tabular}{|c|c|c|}
\hline 24. & Sakit pinggang & $\begin{array}{l}\text { Vakrasana, halasana, } \\
\text { suryanamaskar }\end{array}$ \\
\hline 25. & Penyakit kulit & $\begin{array}{l}\text { Padmasana, sidhasana, } \\
\text { singhasana, virasana, } \\
\text { utkatasna, mandukasana, } \\
\text { suptavajrasana, vrkasana }\end{array}$ \\
\hline 26. & Paru-paru & $\begin{array}{l}\text { Baddhapadmasana, } \\
\text { utkatasana, } \\
\text { sarvangasana, sirsasana, } \\
\text { vrkasana, suryanamaskar }\end{array}$ \\
\hline 27. & $\begin{array}{l}\text { Demam, panas } \\
\text { dalam }\end{array}$ & $\begin{array}{l}\text { Garbhasana, utthita } \\
\text { padmasana, sidhasanan, } \\
\text { gomukhasana }\end{array}$ \\
\hline 28. & Lemah syahwat & $\begin{array}{l}\text { Padmasana, sidhasana, } \\
\text { singhasana, mandukasa- } \\
\text { na, vajrasana, sputa } \\
\text { vajrasana, gomukhasana }\end{array}$ \\
\hline 29. & Darah kotor & $\begin{array}{l}\text { Lolasana, utthita eka- } \\
\text { padmasana }\end{array}$ \\
\hline 30. & Penyakit kaki & $\begin{array}{l}\text { Baddha padmasana, } \\
\text { utkatasana, akaran dha- } \\
\text { nurasana, padmasana }\end{array}$ \\
\hline 31. & Batu ginjal & $\begin{array}{l}\text { Matsyendriyasana, mat- } \\
\text { syasana, vajrasana }\end{array}$ \\
\hline
\end{tabular}

(Sumber : somvir, 2010: 9-11)

Menurut Ghooi (2005: 59-61) untuk menjadi sehat maka seseorng harus memahami definisi kesehatan secara utuh dan menyeluruh. Banyak yang berdampat bahwa kesehatan adalah fisik belaka. Jika seseorang makannya enak, banyak makan, gemuk maka seserang dikatakan sudah sehat. Yang disebut dengan sehata adalah keseluruhan aspek tubuh manusia, baik jasmani maupun rohani. Kesehatan adalah kondisi normal manusia, hidup sesuai dengan hokum alam untuk menjaga tubuh, pikiran, dan jiwa serta lingkungan. Manusia disebut sehat apabila sehat secara fisik, mental, emosional, social, dan spiritual. Ayurweda menyebutkan hal tersebut dalam istilah kosha yaitu: Anamaya kosha (tubuh fisik), pranamaya kosha (tubuh vital), manomaya kosha (tubuh mental), vigyamaya kosha (tubuh intelektual), dan anandmaya kosha (tubuh berkah). Pada dasarnya manusia harus sehat pada tingkatan mental dan spiritual, emosional dan fisik, dan fisikal. Untuk itu yoga memberikan jalan kesehatan secara keseluruhan terhadap manusia. Kesehatan fisik dengan cara mengolah badan melalui yoga asanas, sedangkan kesehatan secara fsikis melalui keseimbangan jiwa dengan samadhi.

\section{Penutup}

Dari pemaparan di atas dapat disimpulkan bahwa yoga merupakan salah satu dari sistem filsafat India yang mengajarkan manusia untuk memahami diri, jiwa, dan bagaimana cara menyatukan antara diri dan jiwa. Yoga tidak saja mengajarkan hal yang bersifat psikis namun mengajarkan bagaimana cara memelihara fisik agar antara fisik dan psikis menjadi seimbang. Jika oaring memiliki kesadaran bahwa kesehatan intu sangat penting dalam hisup maka yoga memberikan solusi untuk mencapainya. Kesehatan bukan hanya dilihat dari fisik tetapi secara menyeluruh dalam hidup ini, baik kesehatan spiritual, emosional, fisik, psikis, dan sehat lingkungan

\section{DAFTAR PUSTAKA}

Dwitayasa, I Made. 2013. Jurnal Sanjiwani Vol. 8, No.1, Juni 2013. Fakultas Brahma Widya IHDN Denpasar.

Ghooi Charanjit. 2005. Bhakti dan Kesehatan. Surabaya: Paramita.

IHDN. 2016. Prosiding Seminar Nasional "Kemanfaatan Latihan Fisik dalam Meningkatkan Kesehatan Jasmani dan Rohani menuju kesempurnaan Hidup. Denpasar: IHDN.

Kembar. 2006. Makalah Yoga Asanas. Gianyar. Tidak diterbitkan.

Lalvani Vimla. 2002. Dasar-dasr Yoga. Tidak diterbitkan

Maswinara. 2008. Nawa Darsana Samgraha. Surabaya: Paramita.

Pusparini, Dewi. 2006. Yoga Sadhana Jalan Menuju Ketenangan dan Kebersihan Bhatin. Denpasar: Tidak diterbitkan.

Somvir. 2010. Mari Beryoga. Denpasar: BaliIndia Foundation. 